Biological and Applied Sciences

Vol.60: e17160462, January-December 2017 http://dx.doi.org/10.1590/1678-4324-2017160462 ISSN 1678-4324 Online Edition

\title{
Coexpression of rumen fungal xylanase and bifunctional cellulase genes in Escherichia coli
}

\author{
Ugur Comlekcioglu $^{1 *}$, Merva Gunes ${ }^{1}$, Hanifi Altun ${ }^{1}$, Dilek Ozgun Ekiz ${ }^{1}$, Ashabil Aygan ${ }^{1}$. \\ ${ }^{1}$ Kahramanmaras Sutcu Imam University, Faculty of Science and Department of Biology, Kahramanmaras, Turkey.
}

\begin{abstract}
Rumen fungi inhabit the gastro-intestinal tract of ruminants and the most non-ruminant herbivores. Rumen fungi produce highly active plant cell wall degrading enzymes, therefore they have gained scientific interest. In this study, genes encoding xylanase (xynA-7) and cellulase (celA-5) were amplified from Neocallimastix sp. GMLF7 and Orpinomyces sp. GMLF5, respectively, and expressed in Escherichia coli. XynA-7 was found to be active only on xylan, however CelA-5 had activity both on carboxymethyl cellulose and lichenan. Lichenase activity of CelA-5 was found to be higher than carboxymethyl cellulase activity. The optimal conditions were at pH 6.0 and $40^{\circ} \mathrm{C}$ for CelA5 and at pH 6.5 and $50{ }^{\circ} \mathrm{C}$ for XynA-7. A coexpression vector was constructed to coproduce the XynA-7 and CelA-5 and then transformed into E. coli. The ability of the transformed E. coli strain to produce CMCase, xylanase and lichenase was evaluated. The transformed E. coli strain acquired the capacity to degrade CMC, xylan and lichenan.
\end{abstract}

Key words: Rumen fungi, xylanase, cellulase, coexpression, E. coli

*Author for correspondence: cugur1978@gmail.com 


\section{INTRODUCTION}

The major components of a plant cell wall are cellulose and xylan ${ }^{1}$. Cellulose is composed of insoluble linear chains of $\beta$-D-1,4-linked glucose units and composed of crystalline and amorphous regions ${ }^{2}$. Xylan is a main component of the hemicellulose, and it is a complex polymer consisting of a $\beta$-D-1,4-linked xylopyranoside backbone which is partially substituted with acetyl, arabinosyl, and glucuronosyl side chains ${ }^{3}$. Many microorganisms are capable of degrading and utilizing cellulose and xylan as carbon and energy sources ${ }^{4}$. Cellulase (endo$1,4-\beta$-glucanase, EC 3.2.1.4) randomly attacks the internal O-glycosidic bonds in cellulose, resulting in glucan chains of different lengths 5 . Xylanase (endo-1,4- $\beta$ xylanase, E.C.3.2.1.8) acts on homopolymeric backbone of 1,4-linked $\beta$-Dxylopyranose producing xylooligomers ${ }^{6}$. Cellulases and xylanases are receiving considerable attention because of their potential applications in several industrial processes.

The rumen contains a complex microbial ecosystem, which extracts nutrients from lignocellulosic agricultural by-products ${ }^{7}$. Rumen fungi are obligate anaerobic microorganisms and constitute a significant portion of the rumen microbial biomass ${ }^{8}$. Rumen fungi rapidly colonize plant cell walls ${ }^{9}$. They degrade cell wall carbohydrates such as cellulose and hemicellulose from the plant parts where they attached ${ }^{10}$. This degradation is performed by various highly active cellulases, xylanases, glycosidases and xylosidases of rumen fungi ${ }^{11}$. The cellulolytic and xylanolytic capacity of rumen fungi was also studied in detail by characterizing the enzyme encoding genes. Several cellulase and xylanase encoding genes have been cloned from Neocallimastix sp., Orpinomyces sp. and Piromyces sp. ${ }^{12}$. Recently, 357 glycoside hydrolases, 24 polysaccharide lyases and 92 carbohydrate esterases were reported in the genome of Orpinomyces sp. C1 ${ }^{13}$.

Neocallimastix spp. and Orpinomyces spp. are well studied microorganisms and they have been reported as excellent cellulase and xylanase producers. In this study, we describe the cloning, coexpression and secretion of the xylanase encoding gene xynA-7 from Neocallimastix sp. GMLF7, and cellulase encoding bifunctional gene celA-5 from Orpinomyces sp. GMLF5 in Escherichia coli. We also conducted the partial characterization and examined the activity of the recombinant enzymes.

\section{MATERIALS AND METHODS}

\section{Microorganisms and Growth Conditions}

The rumen fungi were grown in anaerobic medium at $39{ }^{\circ} \mathrm{C}$. Anaerobic medium was prepared according to Orpin ${ }^{14}$ and dispensed into Hungate tubes under strictly anaerobic conditions. Wheat straw was used as energy source for the maintenance media, and glucose was used as energy source to obtain relatively higher amounts of cells for DNA extraction ${ }^{15}$. Escherichia coli strains were grown in Luria-Bertani (LB) broth in a shaking incubator $(150 \mathrm{rpm})$ at $37^{\circ} \mathrm{C}$. The list of fungal and $E$. coli strains is given in Table 1 . 
Table 1. Bacterial strains and plasmids used in this study

\begin{tabular}{|c|c|c|c|}
\hline Strains and plasmids & & Relevant features & Source or reference \\
\hline Strains & & & \\
\hline $\begin{array}{l}\text { Neocallimastix } \\
\text { GMLF7 }\end{array}$ & sp. & Xylanase coding gene $(x y n A-7)$ source & 16 \\
\hline $\begin{array}{l}\text { Orpinomyces } \\
\text { GMLF5 }\end{array}$ & sp. & $\begin{array}{l}\text { Bifunctional cellulase and lichenase } \\
\text { coding gene }(\mathrm{cel} A-5) \text { source }\end{array}$ & 16 \\
\hline E. coli $\mathrm{EC} 1000$ & & Plasmid free strain, $\mathrm{Km}^{\mathrm{r}}$, cloning host & 17 \\
\hline E. coli $\mathrm{MC} 1022$ & & Plasmid free strain, $\operatorname{Str}^{\mathrm{r}}$, cloning host & 18 \\
\hline E. coli $\mathrm{pCTX7}$ & & E. coli EC 1000 carrying pCTX7 & This study \\
\hline E. coli $\mathrm{pGEMC}$ & & E. coli EC1000 carrying pGEMC & This study \\
\hline E. coli $\mathrm{pCTXC-EC}$ & & E. coli EC 1000 carrying pCTXC & This study \\
\hline E. coli $\mathrm{pCTXC}-\mathrm{MC}$ & & E. coli $\mathrm{MC} 1022$ carrying $\mathrm{pCTXC}$ & This study \\
\hline Plasmids & & & \\
\hline pCT & & $A m p^{r}$, cloning vector & Favorgen (Taiwan) \\
\hline pGEM-T Easy & & $A m p{ }^{r}$, cloning vector & Promega (USA) \\
\hline pCTX7 & & $\begin{array}{l}\text { Amp }{ }^{\mathrm{r}} \text {, derivative of } \mathrm{pCT} \text { vector containing } \\
x y n A-7\end{array}$ & This study \\
\hline pGEMC & & $\begin{array}{l}\text { Amp }{ }^{\mathrm{r}} \text {, derivative of pGEM-T Easy vector } \\
\text { containing celA }-5\end{array}$ & This study \\
\hline pCTXC & & $\begin{array}{l}\text { Amp }^{\mathrm{r}} \text {, derivative of } \mathrm{pCTX} 7 \text { containing } \\
\text { celA }-5\end{array}$ & This study \\
\hline
\end{tabular}

Genomic DNA Extraction and Polymerase Chain Reaction

Rumen fungi were grown for 2 days and the fungal biomass was harvested by centrifugation at $1250 \mathrm{~g}$ for $10 \mathrm{~min}$. Biomass was frozen using liquid nitrogen and immediately broken down using a Mixer Mill (Retsch MM301). Genomic DNA extraction was performed according to Chen et al. ${ }^{19}$. The xylanase and cellulase encoding genes were amplified from Neocallimastix sp. GMLF7 and Orpinomyces sp. GMLF5, respectively, by using xylanase primers (F: 5'ACTGTTGCTAAGGCCCAATG-3' and R: 5'-ACCCCATTTACCATCGTCATC-3') and the cellulase primers (F: 5'-ATTATATTCATATTCACTGGTTGAA-3' and R: 5'TTAGAATGGTGGGTTAGCATTT-3').

Plasmids and Cloning Strategy

The pCT (Favorgen, Taiwan) and pGEMT-Easy (Promega, USA) vectors were used for construction of xylanase and cellulase expression vectors, respectively. The list of constructed vectors was given in Table 1 . The constructed vectors were transformed into $E$. coli $\mathrm{EC} 1000$ and by using $\mathrm{CaCl}_{2}$ method ${ }^{20}$. Plasmid isolations were carried out with Plasmid Isolation Kit (Vivantis, Malaysia). Cellulase gene digested from pGEMC with EcoRI and ligated into pCTX7. The resultant plasmid (pCTXC) was transformed into E. coli EC1000 and E. coli MC1022. Xylanase and cellulase positive colonies were screened according to Teather and Wood ${ }^{21}$.

\section{Enzyme Assay}

For investigation of the cell-associated and extracellular enzyme activities, transformant $E$. coli strain was transferred to LB broth containing ampicillin $(50 \mu \mathrm{g} / \mathrm{ml})$ and incubated at $37{ }^{\circ} \mathrm{C}$ for $12 \mathrm{~h}$ in a shaking incubator $(150 \mathrm{rpm})$. The culture was centrifuged at $6000 \mathrm{rpm}$ for $10 \mathrm{~min}$ at $4{ }^{\circ} \mathrm{C}$. The supernatant was collected and used as extracellular enzyme. The cell pellet washed twice with 50 
$\mathrm{mM}$ sodium-phosphate buffer ( $\mathrm{pH}$ 6.0) and then broken down by using ball-mill dismembranator (Retsch, Germany) and resuspended in the same buffer. Cellular debris was subsequently removed by centrifugation and the clarified extract used as cell-associated activity. Extracellular and cell-associated enzyme fractions were stored at $-20{ }^{\circ} \mathrm{C}$ until required. Xylanase, cellulase, avicelase and lichenase activities were determined by measuring the amount of reducing sugar released by enzyme fractions incubated with $0.5 \%$ birchwood xylan (Sigma), 0.5\% carboxymethyl cellulose (Sigma), $0.2 \%$ Avicel (Merck), and $0.1 \%$ lichenan (Megazyme), respectively, in $50 \mathrm{mM}$ sodium phosphate buffer ( $\mathrm{pH}$ 6.0). Reducing sugars released were measured by the dinitrosalicyclic acid reagent ${ }^{22}$. One unite of enzyme activity was defined as the amount of enzyme that releases $1 \mu \mathrm{mol}$ of reducing sugar per minute in the reaction mixture under the assay conditions. Optimum $\mathrm{pH}$ and temperature, $\mathrm{pH}$ and temperature stabilities were determined according to Comlekcioglu et al. ${ }^{23}$.

\section{RESULTS}

\section{Cloning of xynA-7 and celA-5}

The endo- $\beta-1,4$-xylanase (xynA-7) and endo- $\beta$-1,4-glucanase (celA-5) genes were amplified from Neocallimastix sp. GMLF7 and Orpinomyces sp. GMLF5, respectively, using the genomic DNA as the template. The xynA-7 and celA-5 fragments were about 800 and $1500 \mathrm{bp}$ and cloned into pCT and pGEMT-Easy vectors, respectively. The resultant plasmids were named as pCTX7 and pGEMC, and transferred to E. coli EC1000. Recombinant E. coli pCTX7 and E. coli pGEMC strains were produced XynA-7 and CelA5 enzymes, respectively.

\section{Characterization of XynA-7 and CelA-5 activities}

XynA-7 and CelA-5 enzymes were produced from recombinant E. coli strains. The substrate specificities of the recombinant enzymes for xylan, CM-cellulose, lichenan and avicel were determined. The activities were determined for both cell associated and supernatant fraction. The major enzymatic activities of XynA-7 and CelA-5 were found to be cell associated in E. coli. More than $90 \%$ of the XynA-7 and CelA5 activities were recovered from cellular biomass. Therefore, characterization of the enzymes was carried out using the cell associated enzyme in further studies. XynA-7 was found to be active only on xylan. CelA-5 had activity both on CMC and lichenan, however activity of CelA-5 against lichenan was much higher than CMCase activity. Avicelase activity was also tested for CelA-5, however no avicelase activity was detected in CelA-5.

The activities of the two enzymes at various temperatures and $\mathrm{pH}$ values are shown in Figure 1. XynA-7 and CelA-5 displayed their highest activities at 50 and $40^{\circ} \mathrm{C}$, respectively. XynA-7 retained $70 \%$ of its activity after preincubation at $50^{\circ} \mathrm{C}$ for $3 \mathrm{~h}$ in the absence of substrate. The maximum thermal stability was obtained at $40{ }^{\circ} \mathrm{C}$ for CelA-5 and 59\% of activity was still remained after $3 \mathrm{~h}$ incubation, although the CelA-5 activity diminished at $50^{\circ} \mathrm{C}$ after $1 \mathrm{~h}$. The maximum activities were at $\mathrm{pH} 6.0$ for CelA-5 and at pH 6.5 for XynA-7. Enzyme activities greater than $60 \%$ of the highest activity were attained at $\mathrm{pH} 5.0$ to 7.0 for CelA-5 and at $\mathrm{pH} 4.0$ to 8.0 for XynA-7. After preincubation at different $\mathrm{pH}$ values at optimum temperature for 30 min, both enzymes lost more than $60 \%$ of the maximal activity above $\mathrm{pH} 7.0$. 

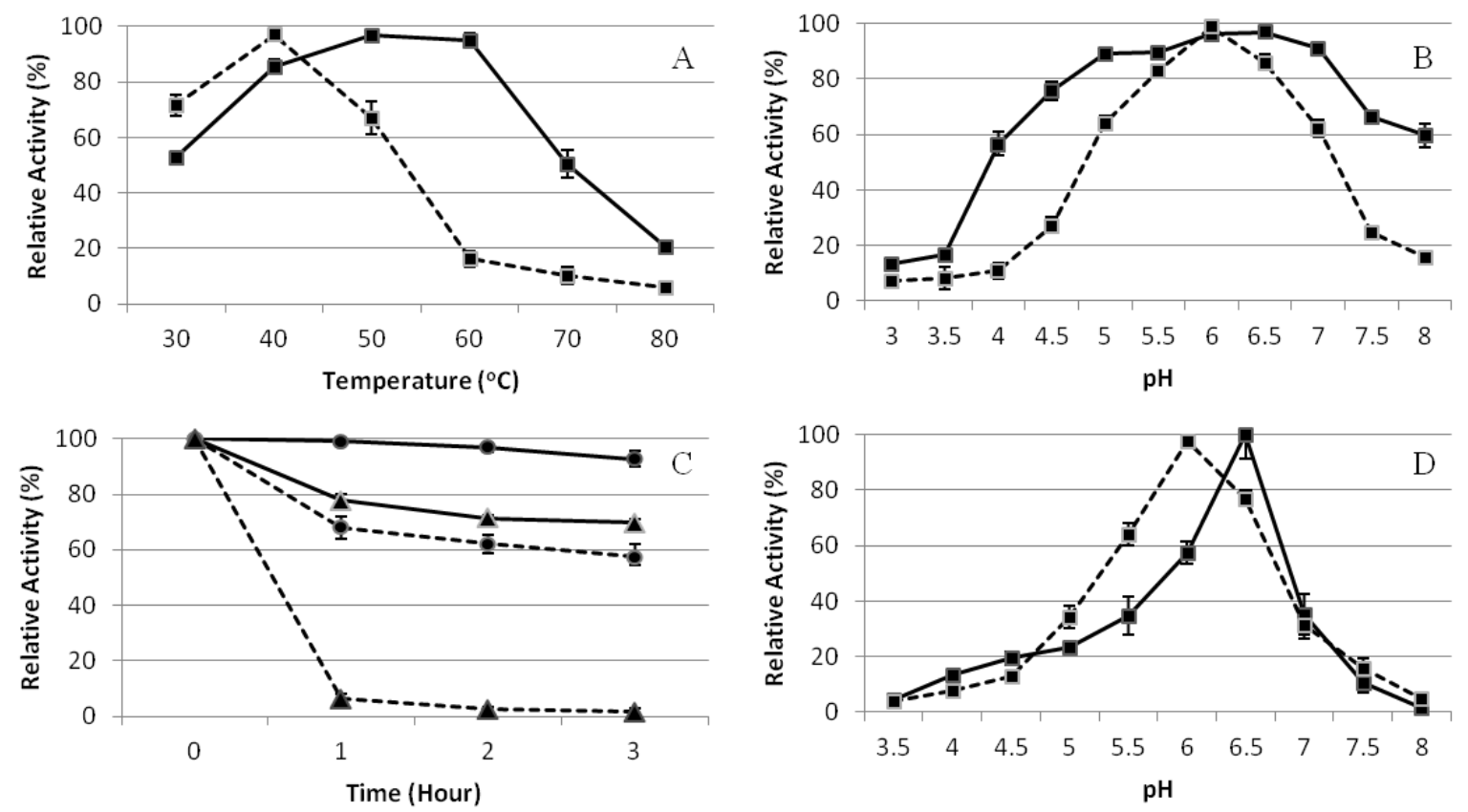

Figure 1. Effects of temperature (A) and $\mathrm{pH}(\mathrm{B})$ on the activities of XynA-7 (solid line) and CelA-5 (dashed line). (C) Thermal stability at $40{ }^{\circ} \mathrm{C}(\mathbf{O})$ and $50{ }^{\circ} \mathrm{C}(\boldsymbol{\Delta})$. (D) pH stability after incubation for $30 \mathrm{~min}$ at optimum temperature.

\section{Construction of co-expression vector}

To coexpress the xynA-7 gene of Neocallimastix sp. GMLF7 (800 bp fragment) and celA-5 gene of Orpinomyces sp. GMLF5 (1500 bp fragment), celA-5 were cloned into the vector pCTX7, generating pCTXC. celA-5 fragment was obtained by digestion from the pGEMC vector using EcoRI, and ligated to a similarly digested pCTX7 (Fig. 2). The resultant plasmid (pCTXC) was then transformed into E. coli EC1000 and E. coli MC1022 as hosts. The presence of the pCTXC in the E .coli transformants was investigated by screening the CMCase activity using Congo red plate assay. A CMCase positive colony was selected and the recombinant plasmid pCTXC was isolated. pCTXC was verified by EcoRI digestion, which produced the celA-5 fragment (1500 bp) (Figure 3). A Congo red plate assay was also used to confirm the xylanase and lichenase activities of the selected CMCase positive transformant. The cell lysates of the E. coli pCTXC strains produced yellow halo zones on the substrate containing plate, indicating that $x y n A-7$ and bifunctional celA5 were functionally coexpressed by pCTXC containing $E$. coli transformants (Fig. 4). Enzyme production of E. coli EC1000/pCTXC was found to be higher than $E$. coli $\mathrm{MC1022/pCTXC}$, hence pCTXC harboring E. coli $\mathrm{EC} 1000$ was used in further studies. 


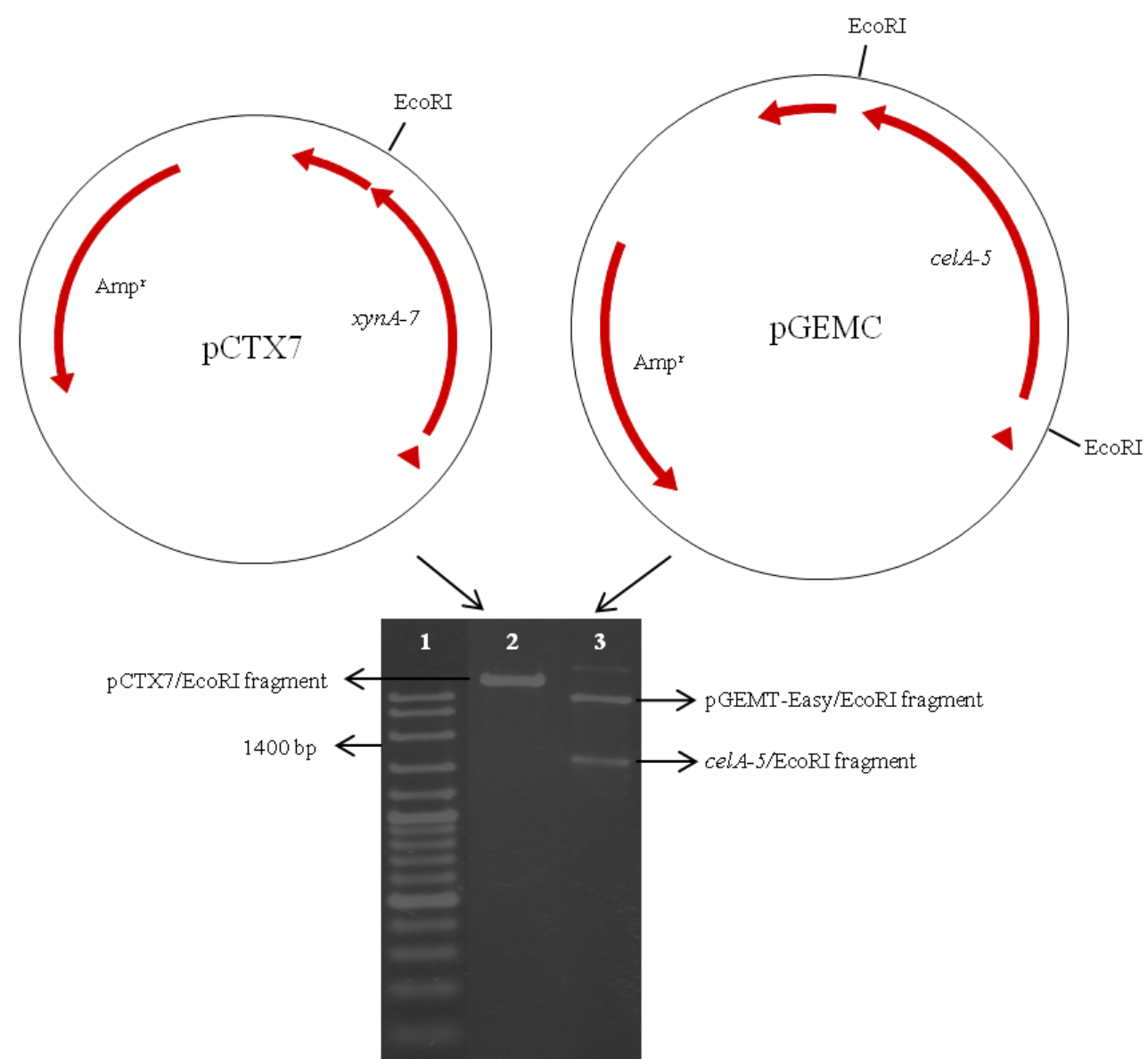

Figure 2. Schematic diagram of xylanase gene containing pCTX7 and bifunctional gene containing pGEMC. pCTX7 and pGEMC were digested with EcoRI, celA-5-EcoRI fragment was isolated from the gel and ligated to pCTX7-EcoRI fragment. Lane 1, 100 bp ladder; lane 2, EcoRI digestion of pCTX7; lane 3, EcoRI digestion of pGEMC.

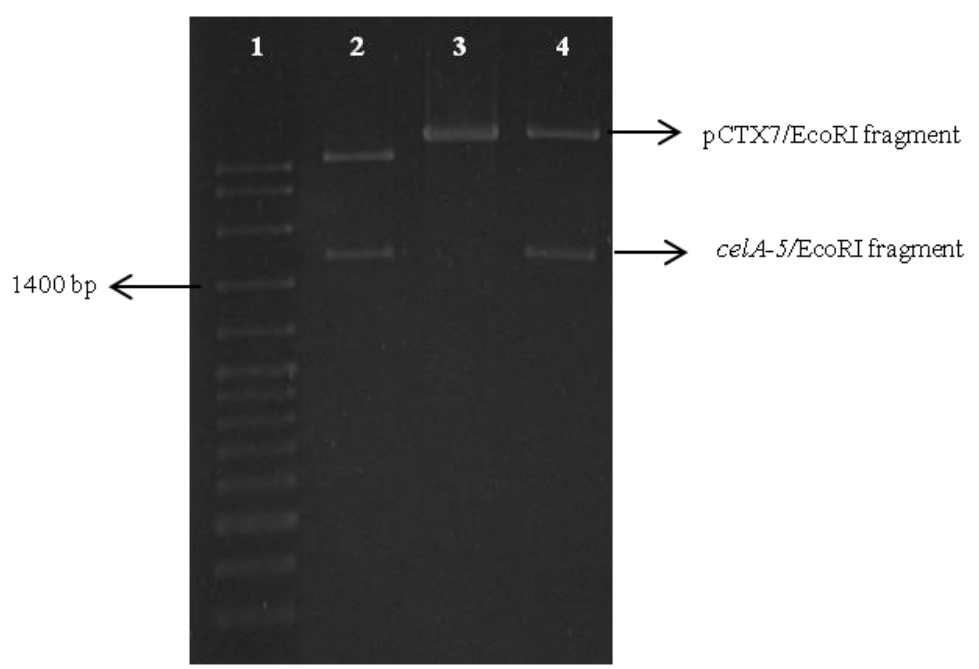

Figure 3. Confirmation of celA-5 gene in pCTXC by EcoRI digestion. Lane 1, 100 bp ladder; lane 2, EcoRI digestion of pGEMC; lane 3, EcoRI digestion of pCTX7; lane 4, EcoRI digestion of pCTXC. 

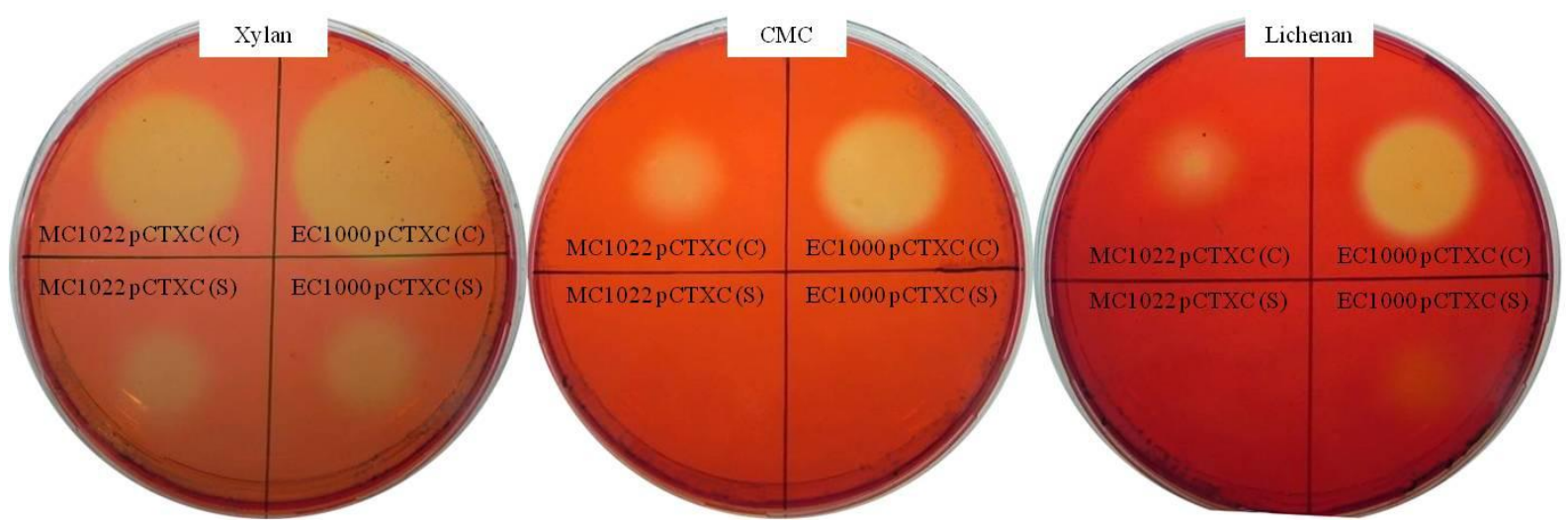

Figure 4. Plate tests for xylanase, CMCase and lichenase activities of pCTXC harboring E. coli EC1000 and MC1022. Extracellular (S) and cell associated (C) enzyme fractions were pipetted onto xylan, CMC and lichenan containing agarose plates, allowed to incubate and stained with Congo red.

\section{Enzyme production of E. coli pCTXC strains}

When cultured in the LB medium at $37^{\circ} \mathrm{C}$, E. coli pCTXC reached stationary growth after $12 \mathrm{~h}$, which was similar to that observed for E. coli EC1000 (data not shown). The specific activities of $x y n A-7$ and celA-5 were determined in the LB medium. The host strain E. coli EC1000 did not show any activity. The highest activities observed for xylanase, CMCase and lichenase of E. coli pCTXC were 30.88, 1.83 and $11.48 \mathrm{U}$ $\mathrm{ml}^{-1}$, respectively. Xylanase and lichenase activities of pCTXC were similar with XynA-7 and CelA-5 expressed from separate promoters. As shown in Table 2, the xylanase and lichenase activity in the extracellular fraction of the E. coli pCTXC culture were much higher than that of the cell associated fraction. However, CMCase activity of cell associated fraction of E. coli pCTXC was lower from the extracellular fraction.

Table 2. The activity of fibrolytic enzymes of $E$. coli strains

\begin{tabular}{lllllll}
\hline Strain & \multicolumn{3}{l}{ Enzyme activity $\left(\mathrm{U} \mathrm{ml}^{-1}\right)$} \\
\cline { 2 - 7 } & \multicolumn{3}{l}{ Xylanase } & \multicolumn{3}{l}{ CMCase } \\
\cline { 2 - 7 } & $\begin{array}{l}\text { Cell } \\
\text { Associated }\end{array}$ & Supernatant & $\begin{array}{l}\text { Cell } \\
\text { Associated }\end{array}$ & Supernatant & $\begin{array}{l}\text { Cell } \\
\text { Associated }\end{array}$ & Supernatant \\
\hline $\begin{array}{l}\text { E. coli } \\
\text { EC1000 }\end{array}$ & $\mathrm{Nd}^{*}$ & $\mathrm{Nd}$ & $\mathrm{Nd}$ & $\mathrm{Nd}$ & $\mathrm{Nd}$ & $\mathrm{Nd}$ \\
$\begin{array}{l}\text { E. coli } \\
\text { pCTX7 }\end{array}$ & $29.89 \pm 0.91$ & $3.23 \pm 0.06$ & $\mathrm{Nd}$ & $\mathrm{Nd}$ & $\mathrm{Nd}$ & $\mathrm{Nd}$ \\
$\begin{array}{l}\text { E. coli } \\
\text { pGEMC }\end{array}$ & $\mathrm{Nd}$ & $\mathrm{Nd}$ & $2.14 \pm 0.35$ & $1.38 \pm 0.15$ & $10.62 \pm 0.27$ & $1.52 \pm 0.73$ \\
$\begin{array}{l}\text { E. coli } \\
\text { pCTXC }\end{array}$ & $30.88 \pm 0.76$ & $4.20 \pm 0.13$ & $0.93 \pm 0.18$ & $1.83 \pm 0.14$ & $11.48 \pm 0.28$ & $1.50 \pm 0.13$ \\
\hline
\end{tabular}

\section{DISCUSSION}

Enzyme supplementation to improve the feed utilization by ruminants has an increasing attention. Supplementing dairy cow and feedlot cattle with fibrolytic enzymes has potential for improving the efficiency of feed utilization and animal performance ${ }^{24}$. Fibrolytic enzyme mixture is reported to enhance the milk yield of cows in early lactation without changing feed intake ${ }^{25}$. Complete degradation of cellulose and hemicellulose in feeds requires a number of enzymes ${ }^{26}$. Recently, 
recombinant DNA technology has enabled the bacteria to coexpress the specific genes. Genes encoding superior genes can be combined in a vector and transferred into well characterized microbial hosts.

Rumen fungi produce a wide range of plant cell wall degrading enzymes that enable them to utilize fibrous plant biomass efficiently. Studies on the functional transfer of rumen fungal genes to tractable bioprocessing hosts are rapidly emerging ${ }^{27}$. In this study, xylanase encoding $x y n A-7$ and cellulase and lichenase encoding bifunctional celA-5 were cloned into E. coli and we performed partial characterization of XynA-7 and CelA-5. Both enzymes showed maximum activity in the range of $40-50^{\circ} \mathrm{C}$ and pH 6 to 6.5. Optimum $\mathrm{pH}$ and temperature values are found to be similar with other rumen fungal enzymes ${ }^{28,29,11}$. The similar optimum activities of XynA-7 and CelA5 are a prominent property for the simultaneous production of both enzymes in the same host.

E. coli has a number of benefits for recombinant protein expression, such as low production cost, rapid growth and high yields to produce desired products ${ }^{30}$. While numerous cellulose and xylan degrading enzymes have been cloned in E. coli, to the best of our knowledge, there are few reports representing the co-expression of cellulase and xylanase in E. coli ${ }^{31}$. In this study, two E. coli strains, E. coli EC1000 and $\mathrm{MC1022}$, were tested for the coexpression of xynA-7 and celA-5, and E. coli EC1000 harboring the pCTXC plasmid had more enzyme activity than that of $E$. coli MC1022 containing the pCTXC. These results indicate that difference in E. coli strains are a important factor for high production of coexpressed enzymes. Simultaneous expression of genes can be conducted using either single or multiple plasmids in $E$. coli, and in the case of a single plasmid, genes can be controlled by single or seperate promoter ${ }^{30}$.

\section{CONCLUSION}

We have established a coexpression system for the production of XynA-7 and bifunctional CelA-5 in E. coli. Coexpressed xylanase and bifunctional cellulase enzymes exhibited properties similar to those of the individually expressed enzymes. In addition to XynA-7 and CelA-5, other polysaccharide degrading enzymes used in animal nutrition, waste treatment, paper manufacturing and fuel production could also be combined in co-expression systems. The use of a single host cell for the production of enzymes may allow for cost-effective enzyme formulations. Additionally, coexpression vectors could also be designed with different strategies, such as using other genes, various promoters and selection markers in order to obtain high production and specifity.

\section{ACKNOWLEDGEMENT}

This work was supported by Kahramanmaraş Sutcu Imam University (Grants: 2012/2-13YLS and 2011/4-14YLS). We gratefully thank Dr. Ismail Akyol, Dr. Emin Ozkose and Dr. M. Sait Ekinci for their valuable contributions.

\section{REFERENCES}

1-Lee JH, Lim M, Kim M, Heo S, Seo J, Kim Y, et al. Constitutive coexpression of Bacillus endoxylanase and Trichoderma endoglucanase genes in Saccharomyces cerevisiae.J Microbiol Biotechn. 2007; 17(12): 2076.

2-Howard RL, Abotsi E, Van Rensburg EJ, Howard S. Lignocellulose biotechnology: issues of bioconversion and enzyme production. Afr J Biotechnol. 2004; 2(12): 602-619. 
3-Katahira S, Fujita Y, Mizuike A, Fukuda H, Kondo A. Construction of a xylan-fermenting yeast strain through codisplay of xylanolytic enzymes on the surface of xylose-utilizing Saccharomyces cerevisiae cells. Appl Environ Microbiol. 2004; 70(9): 5407-5414.

4-Sánchez C. Lignocellulosic residues: biodegradation and bioconversion by fungi. Biotechnol $A d v .2009 ; 27(2):$ 185-194.

5-Kuhad RC, Gupta R, Singh A. Microbial cellulases and their industrial applications. Enzyme Research. 2011; Article ID 280696, 1-10.

6-Juturu V, Wu JC. Microbial xylanases: engineering, production and industrial applications. Biotechnol Adv. 2012; 30(6): 1219-1227.

7-Kamra DN. Rumen microbial ecosystem. Curr Sci India. 2005; 89(1): 124-135.

8-Sirohi SK, Singh N, Dagar SS, Puniya AK. Molecular tools for deciphering the microbial community structure and diversity in rumen ecosystem. Appl Microbiol Biot. 2012; 95(5): 1135-1154.

9-Borneman WS, Ljungdahl LG, Hartley RD, Akin DE. Isolation and characterization of $p$ coumaryl esterase from the anaerobic fungus Neocallimastix strain MC-2. Appl Environ Microbiol. 1991; 57: 2377-2344.

10- Grenet E, Barry P. Colonization of thick-walled plant tissues by anaerobic fungi. Anim Fd Sci Technol. 1988; 19: 25-31.

11- Comlekcioglu U, Ozkose E, Tutus A, Akyol I, Ekinci MS. Cloning and characterization of cellulase and xylanase coding genes from anaerobic fungus Neocallimastix sp. $\begin{array}{llll}\text { GMLF1. Int } \quad J & \text { Agric } & \text { Biol. 2010; } & \text { 12(5): }\end{array}$ 691-696.

12- Krause DO, Denman SE, Mackie RI, Morrison M, Rae AL, Attwood GT, et al. Opportunities to improve fiber degradation in the rumen: microbiology, ecology, and genomics. FEMS Microbiol Rev. 2003; 27(5): 663-693.

13- Youssef NH, Couger MB, Struchtemeyer CG, Liggenstoffer AS, Prade RA, Najar FZ, et al. The genome of the anaerobic fungus Orpinomyces sp. strain $\mathrm{C} 1 \mathrm{~A}$ reveals the unique evolutionary history of a remarkable plant biomass degrader. Appl Environ Microbiol. 2013; 79(15): 4620-4634.

14- Orpin CG. Studies on the rumen flagellate Sphaeromonas communis. J Gen Microbiol. 1976; 94: 270-280.

15- Comlekcioglu U, Ozkose E, Akyol I, Yazdic FC, Ekinci MS. Expression of $\beta-(1,3-1,4)-$ glucanase gene of Orpinomyces sp. GMLF18 in Escherichia coli EC1000 and Lactococcus lactis subsp. cremoris MG1363. Turk J Biol. 2011; 35: 405-414.

16- Çömlekçioğlu U, Akyol İ, Kar B, Özköse E, Ekinci MS. Anaerobik rumen funguslarının izolasyonu, tanımlanması ve kültür koleksiyonunun oluşturulması. Hayvansal Üretim. 2008; 49(2): 29-35.

17- Leenhouts KJ, Buist G, Bolhuis A, ten Berge A, Kiel J, Mierau I, et al. A general system for generating unlabeled gene replacements in bacterial chromosomes. Mol Gen Genet. 1996; 253: $217-224$.

18- Casadaban MJ, Cohen SN. Analysis of gene control signals by DNA fusion and cloning in Escherichia coli. J Mol Biol. 1980; 138(2): 179-207.

19- Chen H, Hopper SL, Li XL, Ljungdahl LG, Cerniglia CE. Isolation of extremely AT-rich genomic DNA and analysis of genes encoding carbohydrate-degrading enzymes from Orpinomyces sp. strain PC-2. Curr Microbiol. 2006; 53(5): 396-400.

20- Mandel M, Higa A. Calcium-dependent bacteriophage DNA infection. J Mol Biol. 1970; 53: $159-162$.

21- Teather RM, Wood PJ. Use of Congo red-polysaccharide interactions in enumeration and characterization of cellulolytic bacteria from the bovine rumen. Appl Environ Microbiol. 1982; 43: 777-780.

22- Miller GL. Use of dinitrosalicylic acid reagent for determination of reducing sugars. Anal Chem. 1959;

31: $426-428$.

23- Comlekcioglu U, Tutus A, Cicekler M, Gunes M, Aygan A. Application of recombinant xylanase from Orpinomyces sp. in elemental chlorine-free bleaching of kraft pulps. Rom Biotech Lett. 2014; 19(1): 8941-8949. 
24- Beauchemin KA, Colombatto D, Morgavi DP, Yang WZ. Use of exogenous fibrolytic enzymes to improve feed utilization by ruminants. J Anim Sci. 2003; 81: E37-E47.

25- Rode LM, Yang WZ, Beauchemin KA. Fibrolytic enzyme supplements for dairy cows in early lactation. J Dairy Sci. 1999; 82(10): 2121-2126.

26- McAllister TA, Hristov AN, Beauchemin KA, Rode LM, Cheng KJ. Enzymes in ruminant diets. In: Bedford MR, Partridge GG. editors. Enzymes in Farm Nutrition. London: Oxon: Cab International; 2001. p. 273-298.

27- Haitjema CH, Solomon KV, Henske JK, Theodorou MK, O'Malley MA. Anaerobic gut fungi: Advances in isolation, culture, and cellulolytic enzyme discovery for biofuel production. Biotechnol Bioeng. 2014; 111(8): 1471-1482.

28- Li XL, Chen H, Ljungdahl LG. Two cellulases, CelA and CelC, from the polycentric anaerobic fungus Orpinomyces strain PC-2 contain N-terminal docking domains for a cellulase-hemicellulase complex. Appl Environ Microbiol. 1997; 63(12): 4721-4728.

29- Huang YH, Huang CT, Hseu RS. Effects of dockerin domains on Neocallimastix frontalis xylanases. FEMS Microbiol Lett. 2005; 243(2): 455-460.

30- Liu M, Yu H. Co-production of a whole cellulase system in Escherichia coli. Biochem Eng J. 2012; 69: 204-210.

31- Adlakha N, Rajagopal R, Kumar S, Reddy VS, Yazdani SS. Synthesis and characterization of chimeric proteins based on cellulase and xylanase from an insect gut bacterium. Appl Environ Microbiol. 2011; 77(14): 4859-4866. 